\title{
THE INDUSTRIAL NETWORK AND THE ROLE OF THE PROFESSIONAL ILLUSTRATOR IN SPAIN
}

\author{
Alfonso Berroya Elosua \\ Centro Pixels (Bilbao). Director and coordinator of the 2D and Concept Art areas
}

\section{Maitane Echevarria Aguirre}

University of the Basque Country. Master in Research and Creativity in Art

\begin{abstract}
The crisis of the publishing industry shows the precarious situation of the professional illustrator in Spain, which does not seem to improve in recent years. Job opportunities are hindered by competition at the international level after the appearance of the Internet, and the decrease of commissions, which are mostly assumed by highly experienced professionals. This situation makes it difficult to access the labor market, where the absence of official rate charts makes it complicate to budget jobs for the less experienced ones. Contrasting with this reality, the booming industries of video games and animation movies demand new professionals, but the lack of academic professionalization in traditional training system limits the possibilities of finding work due to the lack of preparation, forcing future professionals to depend on self-taught education or training in specialized private centers, being these economically less accessible.
\end{abstract}

\section{Keywords: ILLUSTRATION; CONCEPT ART; VIDEO GAMES; ANIMATION} MOVIES; RATES; ARTISTIC LABOUR MARKET IN SPAIN

\section{EL TEJIDO INDUSTRIAL Y EL PAPEL DEL ILUSTRADOR PROFESIONAL EN ESPAÑA}

\section{Resumen}

La crisis de la industria editorial evidencia la precaria situación del ilustrador profesional en España, que no parece mejorar en los últimos años. Las posibilidades laborales se ven lastradas por la competencia a nivel internacional tras la aparición de internet, y la disminución de encargos, que son asumidos en su mayoría por profesionales con gran experiencia. Esta situación dificulta las posibilidades de acceder al mercado laboral, donde la ausencia de tablas de tarifas oficiales complica poder presupuestar trabajos a los menos experimentados. Contrastando con esta realidad, las industrias en auge de los videojuegos y del cine de animación demandan nuevos profesionales, pero la falta de profesionalización académica en la formación tradicional limita las posibilidades de encontrar trabajo por la falta de preparación, obligando a los futuros profesionales a depender de la formación autodidacta o a formarse en centros privados especializados, siendo estos económicamente menos accesibles.

\section{Palabras clave: ILUSTRACIÓN; CONCEPT ART; VIDEOJUEGOS; CINE DE ANIMACIÓN; TARIFAS; MERCADO DE TRABAJO ARTÍSTICO EN ESPAÑA}

\footnotetext{
Berroya Elosua, Alfonso \& Echevarria Aguirre, Maitane. "The industrial network and the role of the professional illustrator in Spain". AusArt 6 (1): 9-29. DOI: 10.1387/ausart.19459
}

\section{AUSART}




\section{ILLUSTRATION AND ITS CONCEPT}

For many of those who are already dedicated to it or want to turn the illustration into their profession, there is a difficulty to face when analyzing this profession as an artistic medium. We refer to the pejorative comparison that has suffered during history as a professional medium compared to the artistic work recognized as such. In fact, many artists dedicated to illustration through engraving, although in many cases, these works were considered as minor work of the artist.

So much so that, even today, this idea of illustration is still present as "minor art". It seems as if the consideration "commercial" or directed to an open public and with great diffusion reduced the work's category. And even taking into account throughout history examples of different artists who have made numerous illustrated work, such as Da Vinci, Delacroix or Goya, among others, the reproduction to the general public with motives away from the most common themes among nobility, clergy and royalty, seemed to give the illustration a category inferior to "great art".

Following this idea, Dr. Ramón Almela (2004) in his article entitled "The illustration. Awakening of the artistic appreciation", underlined these ideas that we were analyzing:

Illustration is considered to be an artistic strategy of lower value than other creations of an elitist aesthetic-creative nature. (....) At the Faculty of Fine Arts in Madrid it is taught in the Drawing Department, always considered -until recently- as a mere assistant in visual production. (...) At present, although the work of illustration is admired, it is also disqualified and discredited on the basis of its function rather than its value. (...) Illustration is not considered art, but only a manifestation of representative craftsmanship. ${ }^{1}$

In this same article, he presents a significant idea: the existing problems in defining the illustrator's profession and his professional skills. He also argues that there is no clear definition of the term illustrator.

One of the evidences that the art world is changing is that the boundaries that divided design, illustration, and painting are rapidly blurring. What makes them different is the intention by which they are created. Illustration is created to 
promote something else: posters, book covers, albums or theatre, which may or may not be in accordance with the artist's ideas and values (Almela 2004).

\section{THE LIMITS OF THE ILLUSTRATION}

And this is where we find the main problem. It seems clear that the idea of illustration that accompanies a text has served to describe the profession in its early days and even in much of the 20th century. In fact, we can divide the history of illustration into two great epochs:

In the long history of book illustration, two major phases must be distinguished. The first goes back to Antiquity (especially Alexandria): manuscripts are decorated with images ("manuscripts with paintings") frequently colored (miniatures, illuminations); by definition, these illustrations are unique works, although several copies are usually made of them. In the second phase, after the invention of the printing press in the first half of the 14th century, techniques were used to multiply the same illustration; these techniques diversified very quickly: wood engraving, metal engraving, lithography, silkscreen printing, photography...2

(Souriau 1998, 667)

It is therefore difficult to delimit the term and its definition. In fact, as we can observe, the term itself presents difficulties for a professional application, since there are problems of indefinition, or lack of concreteness of what it designates for each of them.

Thus, specialized professional industries have preferred to use other words to define the jobs developed by professionals working in the 2D field. AngloSaxon terms such as concept artist, cover artist or storyboard artist are terms derived from the profession of illustrator. Nowadays, however, with the development of new technologies and increasingly technical specialization, there is a tendency to seek qualified professionals in more specific fields.

We postulate that in order to narrow down the range of aspirants, a specialized lexicon has been created, which can be seen in the job offers themselves, where the requirements to be met as specialists are specified. With all this in 
mind, how can we define the profession of illustrator? There is a visible complication: it is difficult to identify the limits and skills that an illustrator can develop when the term itself does not clearly define what these are. The simplicity of the classic definition is far behind: "Printing, engraving or drawing that adorns or documents a book" (RAE $\left.{ }^{3}\right)$.

Are not those pieces collected within a compilation of an illustrator artist illustrations? Are not those backgrounds made either by computer or with traditional procedures, which are used in films, illustrations? What about the fantasy and sci-fi promotional images that advertise a movie? And what about those that are recognizable work of illustrators, and that are marketed on demand?

In this respect, the analysis leads us to believe that as professional need, industry or technological advances have required it, the profession has evolved, deriving its original basis in different fields of action, whether artistic or professional. Historical milestones have profoundly influenced the evolution of the illustration industry, transforming it and in many cases forcing both aspiring young people and renowned professionals to adapt to new specializations.

As an example of this reality, as illustrators and cartoonists begin to be needed to design backgrounds and realize concepts for film production, a new professional branch in the illustration sector is created, in this case known as Concept Art (Norman Rockwell Museum 2015).

As far as the historical context is concerned, this migration of illustrators towards new specialties began in 1935, when Walt Disney began to hire illustrators and cartoonists, many of them of classical tradition, to develop his animated film projects. In the second half of the 1990s, illustrators had to face a very unfavorable situation due to the increase in the price of digital processes in companies and the need for technological equipment that was up to par. Many traditional illustrators with little recognition were relegated to second place and barely able to subsist on their professional lives as illustrators, forcing them to combine their work with other work to support themselves. However, thanks to the Internet era, many businesses and markets required images for marketing and sales purposes (Norman Rockwell Museum 2015).

In addition, the professional branch of animation film and video games gained in relevance and requirements. Thanks to this, teams of illustrators joined companies to design backgrounds and stages for films and video games. This work 
diversified into other fields such as 2D art, texture art and matte paint, among others. In fact, historically, this fact began to be very relevant in the 1970 s.

Thus, thanks to the rise of the fantasy genre, its frontiers lifted the world of cinema with examples such as The Dark Crystal, which was based on designs and drawings of characters and backgrounds made in recent years. It was followed shortly by the success of Star Wars, considered by many to be a work of fantasy rather than science fiction. Famous artists such as Ralph McQuarrie, whose background illustrations served as scenes in the films, or the Swiss artist H. R. Giger, would be the fathers of what is known as "Concept Art". Later, as video games become more complex and graphically finished (such as animated films), they will become standardized as a profession.

It is also helpful to find the New white paper on graphic illustration (2011), published by the Federation of Professional Illustrators' Associations (FADIP), which mentions that illustration is a professional field which borders are blurred and from which new specialized technical professions have been derived:

The term illustrator covers a set of different categories of graphic authors, such as cartoonists, textbook and popular works illustrators, picture book cartoonists, graphic comedians, animators, poster designers, cartoonists for advertising agencies, computer graphic designers and 3D creators, etc. ${ }^{4}$

(FADIP 2011, 13).

These are not all the professional derivations that illustration can have. In fact, we can see that a synergistic process has been created between the video game and animation film sectors, as derived products or merchandising of the original work. In addition, from Alien, Star Wars and Inside the Labyrinth, to mention just a few examples, it became clear that the role of the illustrator was indispensable within animation cinema. Its fundamental role in projecting the director's visions on stages, characters and settings would make it a key part of the production process. This fact would be reflected in the world of video games, not only for illustrators as cover designers, but also for those who migrated to the field of concept design in video games, improving and enriching their lines of art. Today, due to the development of software, techniques and complex production chains, a qualified professional tends to specialize. 


\section{ILLUSTRATION DATA IN SPAIN}

In order to analyze the illustrator's career path, we will use some of the few sources available to us to assess the state of the art. In fact, the lack of literature on the illustration market as such is due, in large part, to the very specific vagueness of its own limits, as we mentioned earlier.

Thus, we use data, articles and reviews collected in the White Papers on graphic illustration in Spain, in their 2004 and 2011 editions, and the study carried out by the Graphic Illustration Observatory in 2009. These data, as can be seen from the date of publication, may be outdated, so that the reflections drawn from them will not be without a certain "bias". Even so, the data, given their generalist nature and also due to the limited evolution of the publishing sector, are still valid today (FADIP 2011, 4).

One of the first things that stand out when analyzing the situation of illustrators in Spain at a professional level is that, according to the Economic Study of Graphic Illustration in Spain (FADIP 2005), "barely $40 \%$ of those who consider themselves illustrators work and make a living from it"5.

This first fact, which is mentioned several times throughout the text, is in itself devastating. We have to understand that almost half of those who want to dedicate themselves to the world of editorial illustration in this country do not make it to the end of the month, at least with the income earned from illustration.

In 2005 it was recorded that $48 \%$ of the professionals in the sample received less than 12,000 euros per year for their professional practice; the reality of the stagnation and in some cases regression of the real rates paid in Spain in recent years suggests that the situation, far from improving, has worsened. Meanwhile, $17 \%$ of the respondents in the sample were not even allowed to cover social security expenses, which made it unfeasible to maintain continuity in their contributions and led to the entry/exit effect of the self-employed workers' scheme (FADIP 2011, 14). Once again we are seeing how precarious the situation really is. This fact shows that approximately half of the illustrators in Spain receive a thousand euros a month or less through their profession, and of these, there is almost a third who do not even cover social security expenses, that is, 275 euros.

Of course, this estimate does not in any way improve the picture we can have of the profession at the moment. Although we must not forget that these are 
data from reports collected between 2004 and 2011 and could be outdated, given the evolution of even sectors such as animation film, which has been hit hard by the crisis, it does not seem that the evolution in this sense tends to improve for this group of professionals:

The illustration sector is made up mostly of independent, dispersed professionals who lack effective means to defend their interests in a concerted manner, given the limitations of both the State's role as guarantor of the legal order and its own corporate development. Added to this is the absence of a single, sufficiently widespread professional protocol establishing minimum guarantees in commissions and contracts, as well as the lack of legally recognized identification of their occupation, given that illustrators are absent from official statistics, do not form any professional sector for the Ministries of Economy and Finance and do not have their own epigraph in the Social Security system ${ }^{6}$.

(FADIP 2011, 14)

With an increasingly diversified and specialized field, where the work of press illustrator and publisher is in a serious crisis, we are in a difficult situation for the newcomer.

During the last few years, however, it seemed that the most industrial sector of video games and animation cinema flourished in Spain at the same rhythm that the drop in sales was evident in comics and in the bad conditions for the editorial illustrator. Nevertheless, it cannot be said that the fields of animation film and video games have avoided the crisis despite their growing success. In animation film, for example, few studios have been able to develop successful products due to the amount of resources needed to make an animated film. In fact, in the EspinOf web interview with Marcos Martínez (2009), we have the example of Planet 51, whose marketing budget alone has been 160 million dollars.

What is clear is that the transformation that the industry itself is undergoing is affecting illustration itself, forcing professionals to adapt to new techniques and markets. In this respect, the report places particular emphasis on this:

In response to the initiative launched in 2005 by FADIP for the Study on the economic participation of the Graphic Illustration in Spain (...), the reality of the Netherlands, Germany, the United Kingdom and France can be seen in general terms. The study seems 
to show that the profession in Europe is far from having achieved a decent economic situation. Suffice it to say that in France, $75 \%$ of those surveyed said they earned less than 12,000 euros a year?.

(FADIP 2008, 34)

With this information we can see that the situation is not unique in this country, but that in others whose reputation in terms of the graphic tradition is undeniable, such as France, they suffer a precarious situation in terms of remuneration, if not worse than ours.

As far as the international market is concerned, the importance of the new fields of digital edition as a possible alternative to the traditional publishing industry is highlighted. It is still worn down today by the crisis and by a profound change in the sector, the consequences of which cannot yet be quantified:

It is therefore essential to address the digital revolution in the analyses that will be carried out from now on -assuming also the importance that the digital revolution continues to have, and is supposed to have for years to come, the means of its "analog" conception - the digital revolution. This means, for everyone, starting from scratch, either from conventions born of traditional means and not necessarily adapted to the new realities, or from other uses that have begun to occur in the absence of another consensus in recent years. Be that as it may, the new rules are yet to be established: none of the usual conventions on the Internet can be freely discussed, and even less when it has not yet reached a point of stabilization in the ongoing changes that are taking place ${ }^{8}$.

(Altuna et al. 2010, 19)

As we can extract from the analysis of the Observatory's Commission (2010), the scope of the digital revolution cannot be quantified or predicted, especially with regard to the use of analog versus digital. This may involve a reconsideration of the industry not only in terms of professional methodology, but also in terms of the medium itself, which is strongly influenced by the progress of a much more globalized industry thanks to the Internet.

Another of the frameworks that is definitely broken in the digital age is that of territories. If it was already common for illustrators to work, either directly or through agencies, with clients from other countries, the new conditions of access to contracting companies (relationship by e-mail and other electronic means) have increased 
the number of cases in which Spanish illustrators earn part or even all of their income from foreign companies ${ }^{9}$.

(Altuna et al. 2010, 34).

It seems that this kind of situation is repeated across the globe. It may be that in times of state-level hiring there are large differences in pay between countries, but as we have already mentioned, as a global industry, prices tend to be commonplace among different regions.

It is worth mentioning the in-depth analysis carried out by this commission with regard to the fiscal situation of illustrators, costs, contracts and similar. In this regard, it must be said that the irregular situation in which many workers in the graphic industry find themselves in the underground economy derives from the problem of dealing with the high quotas of self-employed workers who, in many cases, receiving less than 1,000 euros per month, find it very difficult to maintain a regularized workflow in terms of finances, especially for those who have been in the sector for a year. In any case, the report notes that this situation extends to the majority of workers in the graphic field:

Integrating artists of all kinds into the same analysis allows us to verify that there are situations that are repeated in each of them, such as problems related to Social Security and tax issues (discontinuity and lack of protection is detected in the former, and irregularity of income in the latter) or those related to the contracting and defense of intellectual property rights and similar issues ${ }^{10}$.

$(2010,35)$

\section{THE PROBLEMATIC OF ILLUSTRATION PRICING}

Considering the situation in the sector, it seems clear that strategies are needed to help the illustrator improve his or her position in relation to the competitors, who, as we have seen, are also international. In this sense, there is a demand in the sector for a standardization of price rates, which could help to set at least minimum prices. The aim of these rates would be to serve as a support to beginning illustrators, who are faced with a lack of knowledge about how to budget their orders. The large number of formats, techniques to be used, 
finishes, digital or traditional media, profits depending on the number of copies published, percentage according to copyright, etc., are all variables that are very difficult for a new illustrator to handle.

In this respect, the White Papers are a fundamental support. However, the tables contained in this publication in 2004 on prices and percentages according to works have disappeared in the 2011 version. It is inevitable to ask why. This increases the difficulty of access to information that has a certain official nature, as well as the distrust and uncertainty about secrecy in the illustration industry.

Still, there is an explanation for this lack of concrete data:

The professional associations cannot, in accordance with the legislation in force, propose rates for their members, even if these are only indicative, given that it is assumed that advertising these prices, which are understandable as minimums, would be contrary to free competition in the market (and could be the subject of a disciplinary procedure, as has in fact happened in other professional sectors). On the other hand, there is a clear complexity in establishing rates in a world such as that of illustration, given that prices depend on a multitude of factors, as will be analyzed below ${ }^{11}$.

(FADIP 2011, 9).

This supposes a very interesting dichotomy. On the one hand, it seems that publishing price lists is prohibited by law because it infringes on free competition, but on the other hand, the need for new professionals to have a reference point on which to base their initial negotiations is more than obvious.

The studies agree in stressing the complexity of summarizing a very varied and sometimes ambiguous market in a fixed price table. Depending on the customer, timing, and other factors mentioned above, the price of the same service can vary greatly if we look at Figures 1 and 2 . We are faced with the problem of encrypting a type of work whose professionals themselves do not have a clear consensus on its negative or positive effects on the industry. The debate on this issue extends to many professionals and illustrators' associations, and very few associations publish such 'lists', or, in any case, offer them privately to their members.

In this work we publish the lists that were made at the time, recovered despite their elimination in both white papers, in which they can no longer be found. 
The FADIP itself $(2004,4)$ thus expressed its resolve to eliminate official rates from its own publication:

For this digital edition of the White Paper of the Graphic Illustration in Spain, originally published in 2004, it was decided not to reproduce the rate charts included on pages 82 and 83 . The time since its initial appearance suggests waiting for the publication of new price studies, in preparation at this time ${ }^{12}$.

As we said, the outdated rates (originally published in 2004) and the lack of comparative elements give us an idea of the unobjective bias we would incur if we took this data as a reference model. There are some isolated examples of published rates, but in many cases they belong to a very specific geographical area or location. On other occasions, we will see how it is impossible for us to verify the original source of the data, its context or year of publication, which reduces the reliability of the data reflected therein.

The author of the blog ProcessBlack warns of the dangers of the price tables in illustration, because of the unfair competition that can be established. But in the opinions expressed in the publication itself, we note that it is a solution that is in great demand by a large number of artists with little experience.

This type of lists are dangerous, at least in Spain. On the one hand, not everyone can provide certain services at these prices. There is something called quality that not everyone can give and a list could do a tremendous amount of damage. On the other hand, I am one of those who thinks that surely, if there was a list in Spain (of what is really charged, not what should be charged), in addition to embarrassing ourselves about our rates, it would also be useful for someone to come and lower the prices even more ${ }^{13}$.

(El Tipo Gráfico 2006).

Here seems to be the root of the problem. With price standardization, more experienced workers would be forced to maintain the same price level, as less experienced competitors would charge the same or even less. This would mean the elimination of a margin for negotiation in many cases. In the case of novice authors, moreover, they prefer to lower prices in order to secure a job, which leads to a chain effect of lower prices. It is a saving mentality on the part of the entrepreneur or contractor who, being able to contract the same service for less than the established price, would always opt for the most economic option. 
IVA cuando asf corresponda, según la Ley vigente.

De nuestro comportamiento ante el cliente como profesionales depende que consigamos la consideración y respeto debido.

\section{Cómo utilizar las tablas de tarifas.}

Los importes están expresados en euros.

En cada casilla encontramos 2 cifras:

- La cifra situada a la izquierda y de ta. maño más pequeño corresponde a la tarifa mínima para cada caso, es decir que consideramos que es importante no bajar de dicha cifra, ya que esto supondria obtener una remuneración çue estaria por debajo del valor del trabajo a realizar.

- La cifra situada a la derecha y de tarnaño más grande es la tarifa media que hemos obtenido para cada concepto; esto no significa que sea la tarifa idónea a aplicar en to. dos los casos, sino que constituye una base para que partiendo de clla y teniendo en cuenta los factores antes mencionados, establezcamos la tarifa apropiada aumentando o reduciendo esta cantidad.

Las tarifas mostradas a continuación, corresponden exclusivamente a ilustración; si se requieren diseño gráfico, maquetación, fotogra. fía, etc., debcrán valorarse económicamente aparte.

Para tạifas de diseño gráfico recomendamos consultar el libro El valor del Diseño Grafica e In. dustrial publicado por la ADCV (Asociación de Di. señadores de la Comunidad Valenciana).

Asi como en los trabajos que van a scr editados en papel tenemos en cuenta la tirada inúme. ro de ejemplares) de la edición a la hora de decidir una tarifa, en Internet hablarlamos principalmente del tiempo de utilización de la obra, ya que la difusión es incalculable.

De esta forma debemos valorar si cedemos los derechos por un mayor o menor plazo de tiempo.

\begin{tabular}{|c|c|c|c|c|c|c|c|c|c|c|c|}
\hline ILUSTRACION & $\begin{array}{c}1 / 4 \mathrm{pdg} . \\
/ 2 / \mathrm{x}\end{array}$ & $\begin{array}{l}1 / 2 \text { pia } \\
\text { s/pe }\end{array}$ & $\begin{array}{l}9 i z \\
y / x\end{array}$ & $\begin{array}{l}1 / 4 \text { pls } \\
\text { couce }\end{array}$ & $\begin{array}{l}\text { 1/2 píg. } \\
\text { carot }\end{array}$ & $\begin{array}{l}\text { Prg. } \\
\text { cosot }\end{array}$ & $\begin{array}{l}\text { Pentada } \\
\cdot / n\end{array}$ & $\begin{array}{l}\text { Portada } \\
\text { oover }\end{array}$ & $\begin{array}{c}\text { lina } \\
\text { cómixa }\end{array}$ & Ganicatora & $\begin{array}{l}\% \text { de } \\
\text { rechlos }\end{array}$ \\
\hline Libro de teato & $24 \quad 40$ & 3560 & so 90 & 3650 & go 80 & n 150 & 120180 & iss 300 & & & \\
\hline Libro de balsilic & & $36 \quad 60$ & 50 100 & & 50100 & $x \quad 120$ & 70180 & 183300 & & & 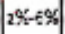 \\
\hline Álbum witzallil & 3D 60 & 1780 & $\infty \quad 310$ & 3070 & bo 120 & 120200 & $180 \quad 250$ & 290350 & & & $4 \times-3 x$ \\
\hline Historista & & & $60 \quad 160$ & & & 120300 & 180300 & 200400 & & & $10 \%$ \\
\hline Revista mensual & & $80 \quad 150$ & 100180 & 120200 & 160360 & 200450 & 300600 & 100900 & 120200 & 150250 & \\
\hline Revisla semanal & & 60100 & 80130 & $\$ 150$ & 30300 & 180400 & 150500 & 300500 & 10018 & $120 \quad 230$ & \\
\hline Pensa diuria & Ba 120 & $100 \quad 140$ & $40 \pm 00$ & 90130 & 120200 & 180300 & & & 20. 15 & $1 \infty \times 00$ & \\
\hline Aublicisod en prensa) & 180 250 & 120280 & 250320 & 300 & $200 \quad 320$ & 300500 & & & & & \\
\hline Hustración científica & 4275 & 60 100: & $90 \quad 150$ & so $\quad 85$ & 75130 & 100250 & & & & & \\
\hline
\end{tabular}

Figure 1. Chart of illustration rates in Spain eliminated in the 2009 edition of the book (Libro Blanco De La Ilustración Gráfica En España 2004). 


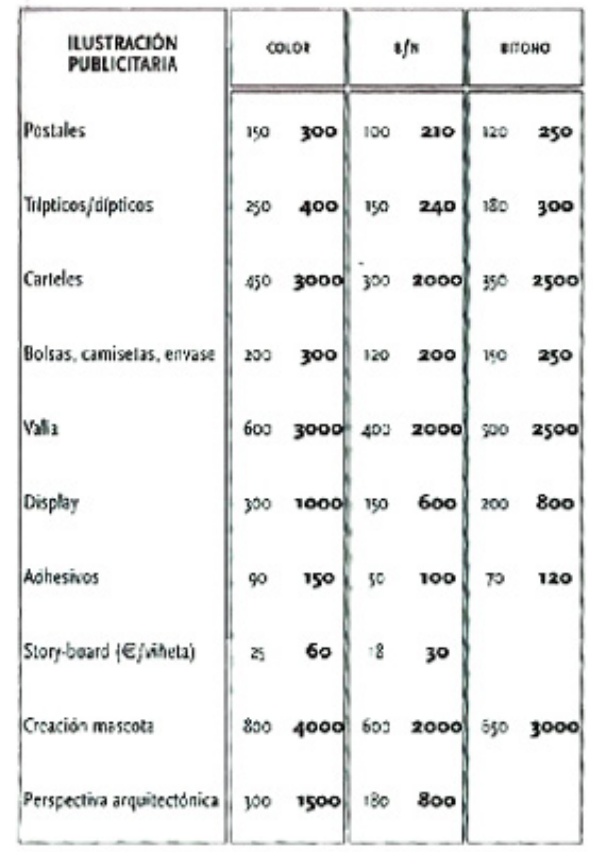

\begin{tabular}{|c|c|c|}
\hline \multirow[b]{2}{*}{ Eanner } & \multicolumn{2}{|c|}{ 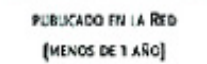 } \\
\hline & 200 & 500 \\
\hline Qrimacion $[€ /$ srganda\} & 60 & 150 \\
\hline Iearos & $2 \mathrm{se}$ & 1200 \\
\hline Anuntios: & 290 & 650 \\
\hline | jueges (incluye programaibal) & 1000 & 6000 \\
\hline
\end{tabular}

\begin{tabular}{|c|c|c|c|c|c|}
\hline ANIMACION & Anim & ván & $\begin{array}{l}\text { Animación } \\
\text { Inimex }[\mathrm{M}]\end{array}$ & $\begin{array}{l}\text { Fulll-an } \\
\text { arecs }\end{array}$ & Imation \\
\hline Story-board $[€$ /vinit1a) & & 6 & 6 & & 12 \\
\hline Lygrout & 6 & 14 & 18 & 18 & 100 \\
\hline Annimscion [Efictograma] & & 1,5 & 1,8 & 6 & 8 \\
\hline Asistencis \{ $\in$ fforogramal & & 0,6 & 0,58 & 3.6 & 4.5 \\
\hline Intecubcion ( $€$ /Tologiams) & & 0,3 & 0.45 & 1.8 & 2,2 \\
\hline Gracion de fordes & 60 & 120 & g0 180 & 200 & 400 \\
\hline Modelo de color de fondos & & 70 & 75 & 100 & 240 \\
\hline Lipiz foncos & & 30 & 24 & 50 & 100 \\
\hline Color fondos & & 30 & 30 & 60 & 120 \\
\hline Crecion personaje & 240 & 300 & $400 \quad 600$ & 1000 & 3000 \\
\hline Modele de color personaje & 40 & 60 & 90 & 120 & 200 \\
\hline
\end{tabular}

Hay otra for ma de cobrar os :rabajos para ln. ternet.

Cuando el orofes onal de la ilustración no di. seña o no aporta ilustración, es decir, cuando sim. plemente hace un trabajo de produccion tanima. ción ce un logo, de unas letras, etc.) se puede cobrar por haras Para ello se utiliza el programa Flash o Dreamiveaver y seria:

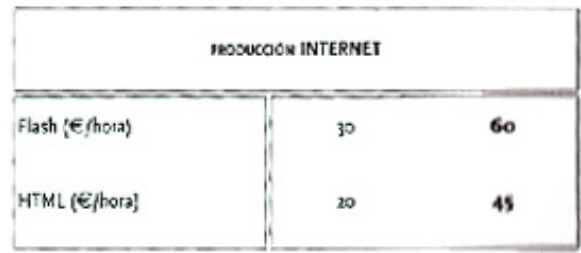

Figure 2. Chart of illustration rates in Spain eliminated in the 2009 edition of the book (Libro Blanco De La Ilustración Gráfica En España 2004) 
As an alternative, we propose a system of hourly rates, where each professional establishes the hourly rate that has to be requested according to his or her own expenses, material, annual salary, etc. This topic is addressed in the Lancetalent blog, where it is intended to reason this problem, making a very interesting analysis by professionals with great experience in the sector. The following is only a sample fragment to illustrate the complications of the general price charts:

(....) we find two alternatives to establish the price of our work, to charge an hourly rate that we set, or to establish our own price chart according to the usual characteristics of the price charts. (...)

- $\quad$ With the price per hour we are building the price from our side, our costs, aspirations.... (....) with this method we do not set a price according to the value that the customer receives or perceives. An example of this risk is the following: if a designer tells his client that he will design a logo for 500 euros based on an hourly price of 50 euros and 10 hours of work, the client may think that 50 euros per hour is excessive and he could back out. But, in reality, based on the designer's portfolio and the value that this work will bring, the client can feel comfortable and consider the price of 500 euros for a logo to be adequate, reasonable and fair.

- $\quad$ We are setting a limit to our earnings: any self-employed person has a limit on the number of hours a day he or she can work, and if they hold on to an hourly rate, they are limiting their potential earnings. (.... $)^{14}$.

(García Torres 2013)

With all that has been mentioned in this section, we can conclude that there is still a demand for minimum rates, but this is a controversial factor, as many experienced illustrators are skeptical of this solution. In addition, the current legislation does not allow its publication because it is contrary to free competition. Thus, as long as it is not altered or specified to allow for a legal exception, reliable rates will not be available. 


\section{THE SITUATION IN THE EDUCATION SECTOR}

In addition to all the above, there is an important factor that makes the professionalization of illustrators more precarious: the lack of specialized training. As far as illustration is concerned, we postulate that it is not represented in current school curricula. In many cases, the degrees in Fine Arts imply a very unspecific transdisciplinary training that makes it difficult to prepare future aspiring illustrators or comic strip artists, both fields with a very high level of specialization required:

(....) in Spain, illustration studies are to be found in Vocational Training; it is therefore a higher vocational training degree and not a 'Bologna degree' (a university degree). In countries such as France, Italy, Holland or Belgium, which consider illustration as a speciality, these are specialization studies of the last years of the degree or object of a specific degree. The Spanish formula affects the time required to study: in other places it takes four years (between common and specific courses), and here only two ${ }^{15}$.

(FADIP 2011, 14).

The fact is that the upper grades, which generally last one and a half years (not including the internship period), do not seem to be sufficient to guarantee an adequate level of training for a student body that enters into direct competition with a highly professional sector and that finds it very difficult to remain economically professional due to the decline of the publishing sector in the first decade of 2000:

Given that the existing information on the process of revision and reform of artistic education, as far as training in illustration, comic strips and animation is concerned, was very unrelated to professional realities and cultural industries (....) it seems clear, with a view to a reform of the curriculum of these studies, that it is necessary to incorporate in training the learning of technologies, not only directed towards illustration in traditional media, but also with at least some introductory material on animation techniques and other applications of increasing use, such as augmented reality. (...) It goes without saying that studies must, of course, provide space in their class hours for an introduction to real professional life - for which a notable presence of illustrators with effective experience 
in the various cultural industries is required among the teaching staff $^{16}$.

(Altuna et al. 2010, 43).

This is where the situation does not seem to have changed. And it is symptomatic that curricula are not able to adapt as quickly as the professional world does. The fields of animation and video games are presented as alternatives, but they are even more technical and specialized industries, and the situation is worsening. In fact, there is a greater presence of academic professors and researchers than of professionalized professors. This affects students' access to the job market after their training period, and they miss more qualifications that tend to lead to a career, such as degrees in design, illustration or video games. This, as we will see, forces those concerned to turn to private and specialized training, which is more expensive than public training.

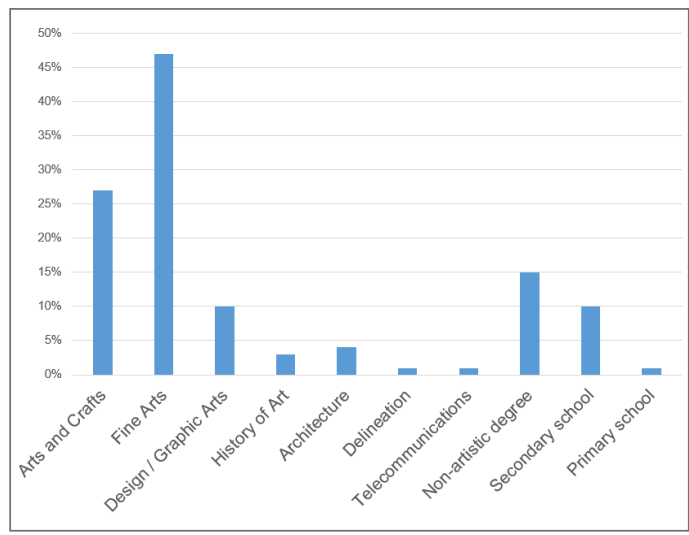

Graph 1. Distribution by study group of people dedicated to professional illustration (Berroya 2017).
In Graph 1 we can see an interesting comparison by study group. We appreciate how, among those students who are dedicated to the world of illustration, the vast majority come from Undergraduate or Bachelor Degree in Fine Arts, or from schools of Arts and Crafts. Surprisingly, the third place is not occupied by other training related to the artistic, but by other studies or degrees that are not of this profile. This can be understood as people interested in this professional profile, who return to the field after having studied another degree.

In fact, as mentioned in the same article, "the vast majority of professionals value between $80 \%$ and $100 \%$ the development of their self-taught capacity as an instrument of recycling and continuous training that allows them to survive and grow professionally"17 (FADIP 2004, 90). From these data we can see how illustrators understand self-taught training as essential for keeping up to date. This reinforces the idea of a lack of professionalization and preparation in traditional training, which does not allow students to be prepared as future professionals in the industry. 


\section{CONCLUSIONS}

From the situation of illustrators in Spain we can draw some conclusions. With regard to the industrial sector, there is not enough data on sales to reliably reflect the state of health of the profession, not even in the white papers or in the specialized committees, since in many cases they show data that may have become obsolete.

Even so, we can understand that the precarious employment situation is derived from the general precariousness of the publishing sector, where experienced professionals monopolize quality work, making it difficult for new authors to access it. They are also affected by the difficulty of pricing their orders, by the problems that exist with the publication of price charts.

This fact is aggravated by the lack of professionalization in traditional academic training, which is not updated quickly enough to provide the industrial sector with students prepared to assume technical roles.

Faced with new synergistic outlets that would allow new niches in the job market, the lack of technical preparation, coupled with the great competition at the international level, places the level of cut to enter the animation and video game industries at a very high point, beyond the reach of most aspiring illustrators. In this way, a new illustrator finds himself or herself in a difficult competitive situation, where he opts for self-study training to specialize, or he or she uses private curricula where the trainers are active professionals, but whose costs are higher than what many students can afford.

This situation could be improved by updating and requiring professional skills from the teaching staff of faculties and training centers, but we also note the need to establish lines of research that could focus on the definition of the editorial term illustration, so as to classify this industry in a concise manner, especially as it refers to economic studies.

\section{References}

Almela Pérez, Ramón. 2004. "La llustración: Despertar de la apreciación artística". Criticarte, 3 agosto. http://www.criticarte.com/Page/file/art2004/Lallustracion.html 
Altuna, Horacio. 2010. Los retos de la era digital: Informe 2009-2010. Informe redactado por la Comisión del Observatorio de la llustración Gráfica, formada por Horacio Altuna... et al. Madrid: FADIP. www.fadip.org/archivos/2010RetosDigital-Observatorio.pdf

Berroya Elosua, Alfonso. 2017. "Estudio de las estrategias profesionales para el cómic y la ilustración en España". Tesis Univ. del País Vasco

El Tipo Gráfico [García, Miguel]. 2006. "Tarifas de diseño gráfico, ilustración y web en Francia". Processblack (blog), 9 jun. www.processblack.com/weblog/tarifas-de-diseno-grafico-ilustracion-y-web-en-francia

FADIP (Federación de Asociaciones de llustradores Profesionales). 2004. Libro blanco de la ilustración gráfica en España. Coord., Carmen Castro. Madrid: FADIP. www.fadip.org/archivos/libroblanco.pdf

— . . 2005. "Estudio económico de la ilustración en España". Madrid: FADIP. www.fadip. org/?page_id $=102$

- . 2011. Nuevo libro blanco de la ilustración gráfica en España: Guía práctica para profesionales de la ilustración. Coord. de obra y preparación de textos, Henrique Torreiro. Madrid: FADIP. www.fadip.org/archivos/NuevoLibroBlancollustracion_web.pdf

García Torres, Lalo. 2013. "Freelance: ¿Cómo cobrar? Precio fijo vs. precio por hora". Lancetalent (blog), 25 abr. www.lancetalent.com/blog/freelance-como-cobrar-precio-fijo-vs-precio-por-hora/

Martínez Carvajal, Marcos. 2009. "Entrevista a Marcos Martínez, Co-Director de 'Planet 51'". Por Juan Luis Caviaro. SpinOf (blog), 21 dic. www.espinof.com/animacion/entrevista-a-marcos-martinez-co-director-de-planet-51

Norman Rockwell Museum. 2015. "Illustration History". www.illustrationhistory.org/history

Souriau, Étienne. 1998. Diccionario Akal de estética. Traducción de Ismael Grasa Adé... et al.; rev. de la ed. española Fernando Castro Flórez. Madrid: Akal

\section{Notes}

${ }^{1}$ Original quote: La ilustración es considerada como una estrategia artística de valor inferior a otras realizaciones de carácter elitista estético-creativo. (...) En la facultad de Bellas Artes de Madrid es enseñada dentro del departamento de Dibujo, siempre considerado -hasta fechas recientes- como mero auxiliar en la producción visual. (...) En el presente, aunque la obra de ilustración es admirada, también es descalificada y desacreditada basándose en su función más que en su valoración. (...) La ilustración no es considerada como arte, sino tan sólo una manifestación de habilidad artesanal representativa (Almela 2004).

2 Original quote: Se debe distinguir, en la larga historia de la ilustración de los libros, dos grandes fases. La primera se remonta a la Antigüedad (especialmente a Alejandría): Ios manuscritos son adornados con imágenes ("manuscritos con pinturas") frecuentemente coloreadas (miniaturas, iluminaciones); por definición, estas ilustraciones son obras únicas, aunque se suelen hacer varias copias de ellas. En la segunda fase, a partir de la invención de la imprenta en la primera mitad del siglo XIV, se recurre a técnicas que permiten multiplicar una misma ilustración; estas técnicas se diversifican muy rápidamente: grabado en madera, grabado en dulce en metal, litografía, serigrafía, fotografía... (Souriau 1998, 667) 
${ }^{3}$ RAE, Diccionario de la Lengua Española, ed. 2018. s.v. “ilustración” http://dle.rae.es/?i$\mathrm{d}=\mathrm{KzZWV} 7 \mathrm{R}$

${ }^{4}$ Original quote: El término ilustrador/a engloba un conjunto de diferentes categorías de autores gráficos, como historietistas, dibujantes de libros de texto y obras de divulgación, dibujantes de álbumes ilustrados, humoristas gráficos, realizadores de animaciones, cartelistas, dibujantes para agencias publicitarias, infografistas y creadores 3D, etcétera (FADIP 2011, 13).

${ }^{5}$ Original quote: apenas un $40 \%$ de quienes se consideran como ilustradores ejercen profesionalmente y viven de ello (FADIP 2005).

${ }^{6}$ Original quote: El sector de la ilustración lo constituyen en su mayor parte profesionales independientes, dispersos y faltos de resortes efectivos en la defensa concertada de sus intereses, dadas las limitaciones de las que adolece tanto el Estado en su papel de garante del orden legal como el propio desarrollo corporativo. A ello se añade la ausencia de un protocolo profesional único, suficientemente extendido, que establezca garantías mínimas en encargos y contratos, así como la carencia de identificación legalmente reconocida de su ocupación, puesto que los ilustradores están ausentes de las estadísticas oficiales, no configuran sector profesional alguno para los ministerios de Economía y Hacienda ni poseen epígrafe propio en la Seguridad Social (FADIP 2011, 14).

${ }^{7}$ Original quote: En respuesta a la iniciativa puesta en marcha en 2005 por FADIP para el Estudio sobre la participación económica de la Ilustración Gráfica en España (...) se puede conocer a grandes rasgos la realidad de Países Bajos, Alemania, Reino Unido y Francia. El estudio parece demostrar que la profesión en Europa está muy lejos de haber conseguido una situación económica digna. Baste como dato que en Francia el 75\% de los encuestados asegura ganar menos de 12.000 euros al año (FADIP 2008, 34).

${ }^{8}$ Original quote: Se hace, pues, imprescindible afrontar en los análisis que se realicen a partir de ahora - asumiendo también la importancia que siguen teniendo, y se supone que tendrán durante años, los medios en su concepción «analógica»_la revolución digital. Eso significa, para todos, partir de cero, o de convenciones nacidas de los medios tradicionales y no necesariamente adecuadas para las nuevas realidades, o bien de otros usos que han comenzado a darse a falta de otro consenso en los últimos años. Sea como fuere, las nuevas reglas están por fijar: ninguna de las convenciones habituales en Internet puede estar libre de discusión, y menos aun cuando no se ha llegado a un momento de estabilización en los cambios continuados que se están dando (Altuna et al. 2010, 19).

${ }^{9}$ Original quote: Otro de los marcos que, definitivamente, queda roto en la era de lo digital es el de los territorios. Si ya era habitual que los ilustradores trabajasen, bien directamente o mediante agencias, con clientes de otros países, las nuevas condiciones de acceso a las empresas contratadoras (relación mediante e-mail y otros medios electrónicos) han incrementado el número de casos en los que los ilustradores españoles ganan parte o incluso la totalidad de sus ingresos de empresas extranjeras (Altuna et al. 2010, 34).

10 Original quote: Integrar en el mismo análisis artistas de todo tipo permite comprobar que hay situaciones que se repiten en cada una de ellas, como pueden ser los problemas relacionados con la Seguridad Social y las cuestiones fiscales (se detecta discontinuidad y desprotección, en cuanto a lo primero, e irregularidad de los rendimientos en cuanto a lo segundo) o los relacionados con la contratación y la defensa de los derechos de propiedad intelectual y similares (Altuna et al. 2010, 35).

11 Original quote: Las asociaciones profesionales no pueden, de acuerdo con la legislación vigente, proponer tarifas para sus asociados, aunque estas sean únicamente orientativas, dado que se supone que publicitar esos precios, entendibles como mínimos, iría en 
contra de la libre competencia en el mercado (y podría ser objeto de expediente sancionador, como de hecho ha ocurrido en otros sectores profesionales). Por otra parte, existe una clara complejidad a la hora de establecer unas tarifas en un mundo como el de la ilustración, dado que los precios dependen de multitud de factores, como se analizará a continuación (FADIP 2011, 9).

${ }^{12}$ Original quote: Para esta edición en formato digital del Libro blanco de la Ilustración Gráfica en España, publicado originalmente en 2004, se ha optado por no reproducir las tablas de tarifas incluidas en las páginas 82 y 83. El tiempo pasado desde su aparición inicial aconseja esperar a la publicación de nuevos estudios de precios, en preparación en estos momentos (FADIP 2004, 4).

${ }^{13}$ Original quote: Este tipo de listas son peligrosas, por lo menos en España. Por un lado, no todo el mundo puede dar determinados servicios a esos precios. Hay algo que se llama calidad que no todo el mundo puede dar y una lista podría hacer mucho daño. Por otro lado, yo soy de los que piensa que seguramente, si existiera una lista en España (de lo que realmente se cobra, no de lo que habría que cobrar), además de para avergonzarnos por nuestras tarifas, también serviría para que venga alguien y baje más aún los precios (EI Tipo Gráfico 2006).

${ }^{14}$ Original quote: (...) nos encontramos con dos alternativas para establecer el precio de nuestro trabajo, cobrar un precio por hora que fijemos, o establecer nuestra propia tabla de precios según las características habituales de las tablas de precio. (...)

- $\quad$ Con el precio por hora estamos construyendo el precio desde nuestro lado, nuestros costes, aspiraciones... (...) con este método no fijamos un precio según el valor que recibe o percibe el cliente. Un ejemplo aclaratorio de este riesgo es el siguiente: si un diseñador le dice a su cliente que le diseñará un logo por 500 euros en base a un precio por hora de 50 euros y 10 horas de trabajo, el cliente puede pensar que 50 euros por hora es algo excesivo y podría echarse atrás. Pero, en realidad, en base al portfolio del diseñador y al valor que va a aportar ese trabajo, el cliente puede sentirse cómodo y considerar adecuado, razonable y justo el precio de 500 euros por un logotipo.

- Estamos fijando un límite a nuestros ingresos: cualquier trabajador independiente tiene un límite de horas al día para trabajar, y si se aferra a un ratio por hora está limitando sus ingresos potenciales. (...) (García Torres 2013)

${ }^{15}$ Original quote: (...) en España se sitúan los estudios de ilustración en Formación Profesional; es, por tanto, un grado superior de FP y no un «grado Bolonia» (una licenciatura). En países como Francia, Italia, Holanda o Bélgica, que contemplan la ilustración como especialidad, son estudios de especialización de los últimos años del grado u objeto de un grado específico. La fórmula española afecta al tiempo que requieren los estudios: en otros lugares implican cuatro años (entre cursos comunes y específicos), y aquí solo dos (FADIP 2011, 14).

${ }^{16}$ Original quote: Dado que las informaciones existentes acerca del proceso de revisión y reforma de las enseñanzas artísticas, en lo que atañía a la formación en ilustración, cómic y animación, aparecían muy desvinculadas de las realidades profesionales y de las industrias culturales (...) parece claro, de cara a una reforma del currículum de estos estudios, es la necesidad de incorporar en la formación el aprendizaje de las tecnologías, no solamente dirigidas a la ilustración en los soportes tradicionales, sino con al menos introducciones a las técnicas de animación y otras aplicaciones de uso cada vez más extendido, como la realidad aumentada. (...) No habría ni que decir que los estudios tienen, por fuerza, que dedicar en sus horas lectivas espacio para una introducción a la vida profesional real - para lo que se hace precisa una presencia notable en el profesorado 
de ilustradores con experiencia efectiva en las distintas industrias culturales (Altuna et al. 2010, 43).

${ }_{17}$ Original quote: La gran mayoría de profesionales valoran entre el $80 \%$ y $100 \%$ el desarrollo de su capacidad autodidacta como instrumento de reciclaje y formación continua que les permite sobrevivir y crecer profesionalmente (FADIP 2004, 90).

(Artículo recibido 15-03-18; aceptado 08-05-18) 